\title{
THE STATUS OF THE BLACK-BROWED AND GREY-HEADED ALBATROSSES ON MACQUARIE ISLAND
}

\author{
by G. R. Copson \\ (with one table)
}

COPSON, G.R., 1988 (viii): The status of the black -browed and grey-headed albatrosses on Macquarie Island. Pap. Proc. R. Soc. Tasm., 122(1): 137 141. Papers presented at the Macquarie Island Symposium, Hobart, May 1987. https://doi.org/10.26749/rstpp.122.1.137 ISSN 0080 4703. Deparıment of Lands, Parks and Wildlife, Hobart, Tasmania, Australia 7000 .

Marginal populations of both black-browed (Diomedea melanophris) and grey-headed (D) chrysostoma) albatrosses breed in the Macquarie Island Nature Reserve. Black browed albatrosses breed in three colonies: one, on North Head, has been declining in numbers since the 1950's; the second, in the southwest corner of the island, has been increasing; the third, on Bishop and Clerk Islets, appears to be larger than the second. Breeding success has been high in the southwest colony over the past ten years, but recruitment of banded youngsters into the breeding population has been very low.

Grey-headed albatrosses, biennial breeders, breed only in the southwest corner of the island, with an apparently stable breeding population. The breeding success is slightly higher than that of the black-browed albatrosses but again recruitment into the breeding population is very low.

First breeding records of birds banded as fledglings are given for both species and these data are used to extrapolate minimum ages for birds banded as adults in the 1950's. Observations from several seasons are combined to construct the breeding cycles of both species at Macquarie Island Nature Reserve.

Key Words: black-browed albatross, grey-headed albatross, breeding cycles, marginal populations, Macquarie Island.

\section{INTRODUCTION}

The first account of albatrosses at Macquarie Island was by Bellinghausen, the Russian explorer, who visited there in November 1820 . He recorded albatrosses being on eggs, and that the sealers were using them as food, but did not record which species (Debenham 1945). Captain Raine (1824) also recorded seeing albatrosses (without mentioning the species) and reported that the sealers were supplementing their rations with young albatrosses, amongst other things. Burton, who was a taxidermist and spend three and a half years on the island in the 1890's, recorded only two albatrosses, the royal and the sooty (Cumpston 1968).

In December 1912, Hamilton collected an albatross from the southwest corner of the island which he identified as a grey-headed albatross, but Falla could not trace this specimen and left the identification open (Falla 1937). During the second season (1930-31) of the British Australian New Zealand Antarctic Research Expedition (BANZARE), mature black-browed albatrosses were plentiful off Macquarie Island but never more than one grey-headed albatross per day was seen in the same area (Falla 1937).

At the present time, black-browed albatrosses breed in three localities in the reserve, the western side of North Head, the southwestern side of Petrel Peak, and Bishop and Clerk Islets, $37 \mathrm{~km}$ south of Macquarie Island. Grey-headed albatrosses only breed on the southern and southwestern flanks of Petrel Peak and there are no records of their having bred in other areas of the reserve.

\section{STUDY AREAS AND METHODS}

The colonies of black-browed albatrosses, both at North Head and on the southwestern flank of Petrel Peak, have been studied intermittently since 1949. Grey-headed albatrosses have been studied since 1952 in the reserve, but again only intermittently. Since 1975, work has been carried out on both species in the colonies of the southwestern corner of the reserve. For this paper, data for the years prior to 1976 were obtained from Australian National Antarctic Research Expedition (ANARE) logs and Australian Bird and Bat Banding Schemes (ABBBS) banding schedules.

The current study has been carried out by the National Parks and Wildlife Service from the 1976-77 season. Nests with eggs were marked with numbered stakes in October or November of each year (except for 1982 when the Service did not have 
anybody overwintering on the island). In four of the seven years of the study, the area was visited again in December to identify as many breeding birds as possible. Hatching success was obtained from a visit in early January and the fledglings were banded in March or April. Breeding success is calculated only on data from the nests marked in October or November, although any other chicks found in subsequent searches were banded. A few chicks found to have died in the colony after banding were counted as not having fledged. Adult birds were banded on an opportunistic basis, but birds on eggs were not banded if they became agitated.

\section{RESULTS}

The combined observations from 1949-85 are incomplete and record only 25 breeding seasons. However, this still allows the construction of breeding timetables for both black-browed and grey-headed albatrosses.

Black-browed albatrosses begin to return to the reserve in the first week of September, the earliest date recorded being 3 September. Laying has been recorded as early as 26 September but most eggs are laid in early October. The dates at which the first chicks have been seen were 8 December 1980 and 10 December 1984. The chick recorded on 10 December was limated to be 3-5 days old and two other chicks were also found to be chipping out of eggs on the same day. The peak of hatching is around the third week of December. Two birds were recorded as still being on eggs on 8 January but both were found to have failed by the next visit. The fledglings leave their nests from the second week of April.

On Macquarie Island, grey-headed albatrosses appear to conform to the biennial breeding pattern and there are no records of birds who have successfully bred one season returning to breed the next season. The first birds return to the island slightly later than black-browed albatrosses, the earliest sighting being on 13 September. Eggs are laid from the middle of October, the peak of laying being about the third week. Hatching commences in the latter half of December, the first records of chipping out being 20 December 1975 and 20 December 1983. Hatching is usually completed by the end of the first week of January. The chicks leave their nests from late April to the middle of May. There is one record of a fledgling still at the nest site on 5 June but it is not known whether it subsequently left the island.
In the 31 seasons from 1954-55 to 1984-85, at least 344 black-browed albatrosses ( 156 adults, 188 pullus) and 572 grey-headed albatrosses (284 adults, 288 pullus) have been banded on Macquarie Island. During this period, banding data are available for 20 seasons for black-browed and 16 seasons for grey-headed albatrosses.

Early ANARE records are incomplete and often difficult to interpret. The records for black-browed albatrosses breeding on North Head from the 1949-50 season to the 1961-62 season mention from $18+$ to 31 pairs, $1+$ to $16+$ eggs laid and 1 to 14 chicks being fledged. Details of eggs laid, chicks hatched and chicks fledged are complete for only three seasons $(1952-53,12,5$ and 3 ; 1955 56, 11,6 and 4; 1956-57, 12, 4 and 2). Over the same period, the sparse records for the southwestern colony give maximum figures of 10 nests (1956-57), 6 eggs (1960-61) and 1 chick fledged (1959-60). The records do not give complete data for eggs laid to chicks fledged for a single season.

The records for grey-headed albatrosses prior to the 1970's are even more sparse than those for black-browed albatrosses. ANARE logs record "about 100 birds", January 1950; "at least 60 on nests", October 1954; "44 nests were counted but no eggs", October 1955; "40 nests estimated", October 1957.

The present breeding population of blackbrowed albatrosses in the Macquarie Island Nature Reserve is estimated at between 60 and 80 pairs (North Head 2-3 pairs; southwestern corner 20-30 pairs; Bishop and Clerk Islets $25+$ pairs (Mackenzie 1968) and 44+ pairs (Lugg et al. 1978)). The greyheaded albatross population is estimated at $80-100$ breeding pairs and is confined to the southwestern corner of Macquarie Island.

The data for both black-browed and grey-headed albatrosses breeding in the southwestern study area during seasons 1977-78 and 1984-85 (excluding 1982-83) are given in table 1. Breeding success calculated from the study area data is $66.9 \%$ for black-browed albatrosses (range from $42.9 \%$ to $86.4 \%$ ) and $72.3 \%$ (range $58.0 \%$ to $85.7 \%$ ) for grey-headed albatrosses (table 1). Over this period the black-browed albatross colony at North Head produced no more than two eggs per season and no chicks fledged. The colony at North Head has decreased since the 1960's and the one at the southwestern corner of the island appears to have increased over the same period. Birds have been banded at both colonies (134 at North Head and 438 in the southwestern corner) but there are no records of banded birds having moved from one colony to the other. 
TABLE 1

Breeding Success* of Black-browed and Grey-headed Albatrosses in Study Area on Macquarie Island**

\begin{tabular}{|c|c|c|c|c|}
\hline \multirow[t]{2}{*}{ Season } & \multirow[t]{2}{*}{ Lgg\$ } & \multicolumn{2}{|c|}{ Chicks } & \multirow{2}{*}{$\begin{array}{c}\text { Breeding } \\
\text { Success } \\
\%\end{array}$} \\
\hline & & hatched & redged & \\
\hline \multicolumn{5}{|c|}{ Black-browed Albatross } \\
\hline $\begin{array}{l}1977-78 \\
1978-79 \\
1979-80 \\
1980-81 \\
1981-82 \\
1982-83 \\
1983-84 \\
1984-85 \\
x( \pm S D)\end{array}$ & $\begin{array}{l}14 \\
27 \\
19 \\
21 \\
22 \\
\text { no data } \\
21 \\
21\end{array}$ & $\begin{array}{l}12 \\
15 \\
16 \\
11 \\
21 \\
\\
15 \\
16\end{array}$ & $\begin{array}{c}12 \\
13 \\
15 \\
9 \\
19\end{array}$ & $\begin{array}{l}85.7 \\
48.1 \\
78.9 \\
42.9 \\
86.4 \\
\\
66.7 \\
71.4 \\
66.9 \pm 17.4\end{array}$ \\
\hline \multicolumn{5}{|c|}{ Grey-headed Albatross } \\
\hline $\begin{array}{l}1977-78 \\
1978-79 \\
1979-80 \\
1980-81 \\
1981-82 \\
1982-83 \\
1983-84 \\
1984-85 \\
x( \pm S D)\end{array}$ & $\begin{array}{l}28 \\
29 \\
30 \\
29 \\
44 \\
\text { no data } \\
31 \\
51\end{array}$ & $\begin{array}{l}25 \\
21 \\
27 \\
27 \\
38\end{array}$ & $\begin{array}{l}24 \\
17 \\
22 \\
18 \\
36\end{array}$ & $\begin{array}{l}58.0 \\
78.4 \\
72.3 \pm 11.5\end{array}$ \\
\hline
\end{tabular}

* eggs laid to chicks fledged

** 1977-78 to $1984-85$ seasons

The ages at which black-browed albatrosses banded as chicks were first resighted in the colony are three as five-year-olds, two as seven-year-olds and two as eight-year-olds. The two seven-yearolds and one eight-year-old were breeding when first resighted and one of the five-year-olds returned to breed as a seven-year-old. As no references have been found to black-browed albatrosses breeding at an earlier age, these seven-yearolds may represent the minimum breeding age for this species under the conditions found at Macquarie Island

The record of the eight-year-old breeding was made in the 1985-86 season (the data are incomplete for this season and not included in table 1). If seven years old is taken as the minimum breeding age, the number of birds banded as chicks which could have returned to breed by the 1985-86 season is 120 . The four birds above are the only ones recorded from chicks to breeding adults, which gives a minimum recruitment rate of $3.3 \%$.
The oldest known age black-browed albatross was eleven years old when last sighted as a breeding bird in the 1984-85 season. Of birds first banded as adults, five were over 23 years old (taking seven years old as the minimum breeding age) the oldest being 29 years old when last sighted.

Seven grey-headed albatrosses banded as chicks have subsequently returned to the colony. One returned as a six-year-old, again as an eightyear-old and was recorded as breeding at ten years old. Another was first sighted as an eleven-year-old but it is not known whether it was breeding. The other five were first resighted as breeding birds, one each as seven-, eight-and nine-year-olds and two as ten-year-olds. To the end of 1978-79 season (i.e. seven years prior to the last season for which data are available) 152 chicks had been banded. This would give a minimum recruitment rate of $3.9 \%$.

The grey-headed albatross first resighted as an eleven-year-old (above) is the oldest known aged bird from the colony. Five birds banded as 
adults have subsequently been resighted in the colony 23 or more years later. If seven years old is taken as the minimum breeding age, these birds would have been at least $30,33,34$ and two 36 years old when last sighted.

\section{DISCUSSION}

The breeding populations of black browed albatrosses (60-80 pairs) and grey-headed albatrosses (80-100 pairs) in the Macquaric Island Nature Reserve are small compared with other breeding grounds. Elsewhere, estimates of breeding populations of black-browed albatrosses range from $200+$ pairs at Heard Island $(\mathbb{R}$. Ledingham, pers. comm.) up to 390000 pairs on the Falkland Islands (Croxall et al. 1984); those for grey-headed albatrosses range from 1000 pairs in the Cape Horn region (Tickell 1976) to 38000 pairs at South Georgia (Prince \& Payne 1979).

The early records of black-browed albatrosses and grey-headed albatrosses at Macquarie Island give no indication of whether the present colonies are remnants of larger populations decimated by sealers and oil-gatherers in the last century or have re-established after being completely exterminated on the island during the commercial era. Alternatively, numbers may always have been small, or the population may have been established in the reserve only since around the turn of the century.

The grey-headed albatross population appears to have remained stable in the reserve since Hamilton discovered a colony of "not more than forty nests" in the southwestern corner of Macquarie Island in December 1912 (Falla 1937).

Black-browed albatrosses were first recorded breeding on Macquarie Island in the 1949-50 season, when both the North Head and southwestern corner colonies were found. It appears very unlikely that these colonies would have been overlooked by members of AAE (1911-14) during their extensive fieldwork around the island. The colony on the Bishop and Clerk Islets was not discovered until 1965 (Mackenzie 1968). This may have been the source of recolonising birds on Macquarie Island, had populations there been exterminated by sealers. The only other colonies in the region are those on Campbell Island $(700 \mathrm{~km}$ away), where both species breed. However, the black-browed albatrosses on Campbell Island are a subspecies Diomedea melanophris impavida and these have never been recorded at Macquarie Island.

Weimerskirch et al. (1986) showed that around Isles Crozet and Kerguelen Diomedea melanophris forages over the continental shelf, whereas $D$. chrysostoma range further afield to the colder subantarctic and antarctic waters. They also suggest a link exists between the size of a breeding population of D. melanophris and the extent of the continental shelf around the breeding site, i.e. the greater the extent of the continental shelf the larger the breeding population of black-browed albatrosses. If this is the case, Macquarie Island may never have supported a large breeding population of black-browed albatrosses, as it has virtually no continental shelf.

The breeding cycles of both species on Macquarie Island are similar to those of the birds breeding on Campbell Island, with black-browed albatrosses returning to the nesting sites and also laying approximately two weeks earlier than greyheaded albatrosses. Also, on the Falkland Islands black-browed albatrosses begin to return to their breeding colonies about the same time as those at Macquarie Island. In contrast, on South Georgia (Tickell \& Pinder 1975) and Isles Crozet (Weimerskirch etal. 1986) grey-headed albatrosses return to their breeding colonies, and also lay their eggs, earlier than black-browed albatrosses.

A study of black-browed and grey-headed albatrosses at Bird Island, South Georgia, shows the breeding success (percentage of chicks fledged from eggs laid) to be lower for both species than at Macquarie Island. The results for Bird Island were black-browed albatrosses $37.8 \% \pm 22.7$ and greyheaded albatrosses $46.4 \% \pm 12.9$ (Prince 1985); for Macquarie Island the results were $66.9 \%>17.4$ and $72.3 \% \pm 11.5$ respectively. In both studies the breeding success of black-browed albatrosses varied more from year to year than that of grey-headed albatrosses. This may be due to black-browed albatrosses having more limited foraging grounds than grey-headed albatrosses (Weimerskirch et al 1986), making them more susceptible to local fluctuations in their food supply. This is further supported by the two worst breeding seasons for black-browed albatrosses in the Bird Island study (1977-78, 11.4\% and 1979-80 complete failure, Prince 1985) corresponding to breeding successes of $85.7 \%$ and $78.9 \%$ on Macquarie Island. Although minimum recruitment rates for both species have been given in the results, the data are insufficient to predict any long-term trends in these colonies.

In carrying out studies on marginal populations such as black-browed albatrosses on Macquarie Island, there is a problem of obtaining acceptable scientific results without causing permanent detrimental effects. The effects of studies must be balanced against the long-term benefits for 
the species being studied, and the National Parks and Wildlife Service in its management of the reserve regulates the nature of proposed studies accordingly.

\section{ACKNOWLEDGEMENTS}

The data presented in this paper have been collected by ANARE personnel over many years and I would like to thank them for their efforts. Errors of inte rpretation are mine. I would also like to thank the Tasmanian National Parks and Wildlife Service and the Antarctic Division of the Department of Science for making possible my stays on Macquarie Island. The Antarctic Division also made available the ANARE logs from 1948 to 1976. Australian Bird and Bat Banding Scheme supplied bird bands used in the study.

\section{REFERENCES}

CROXALL J.P., McINNES, S.J. \& PRINCE, P.A., 1984: The status and conservation of seabirds at the Falkland Islands. In Croxall, J.P., Evans, P.G.H. \& Schreiber, R.W. (Eds): STATUS AND CONSERVATION OF THE WORLD'S SEA BIRDS. ICBP Technical Publication No.2: 271-291.

CUMPSTON, J.S. 1968: Macquarie Island. $A N A R E$ Sci. Rep., Ser. A(1). Antarctic Division, Department of External Affairs, Melbourne, Australia.
DEBENHAM, F. (Ed.), 1945: THE VOYAGE OF CAPTAIN BELLINGHAUSEN TO THEANTARCTIC SEAS, 1819-1821. Transprinted by Hakluyt Society.

FALLA, R.A. 1937: Birds. BANZARE Rep., Ser. B(2). LUGG, D.J., JOHNSTONE, G.W. \& GRIFFIN, B.J. 1978: The outlying islands of Macquarie lsland. Geogr. J., 144(2): 277-287.

MACKENZIE, D., 1968: The birds and seals of Bishop and Clerk Islets, Macquarie Island. Emu, 67: $241-245$.

PRINCE, P.A., 1985: Population and energetic aspects of the relationship between blackbrowed and greyheaded albatrosses and the Southern Ocean marine environment. In Siegfried W.R., Condy, P.R. \& Laws, R.M. (Eds): ANTARCTIC NUTRIENT CYCLES AND FOOD WEBS. Springer-Verlag.

PRINCE, P.A. \& PAYNE, M.R., 1979: Current status of birds at South Georgia. Bull. Brit. Antarct. Surv., 48: 103-118.

RAINE, T., 1824. Notice in regard to Macquarie Island. Edin. Philos. J., XI: 46-50.

TICKELL, W.L.N., 1976: The distribution of blackbrowed and grey-headed albatrosses. Emu, 76: 64-68.

TICKELL, W.L.N. \& PINDER, R., 1975: Breeding biology of the black-browed albatross Diomedea melanophris and grey-headed albatross $D$. chrysostoma at Bird Island, South Georgia. Ibis, 117(4): 433-451.

WEIMERSKIRCH, H., JOAVENTIN, P. \& STAHL, J.C., 1986: Comparative ecology of six albatross species breeding on the Crozet Islands. Ibis, 128: 195-213.

(accepted 5 October 1987) 